Ambient Science, 2018: Vol. 05(1); 01-05

DOI:10.21276/ambi.2018.05.1.ga01

ambient

SCIENCE

Published by: National Cave Research and Protection Organization, India

Vol. 05(1):01-05

Year 2018

GENERAL ARTICLE

\title{
Role of Modern Architecture in Achievement of Sustainability in Contemporary Society
}

\section{Elyar Rostami Sobhani*, Faranak Moghadam Far}

Department of Architecture, Maragheh Branch, Islamic Azad University, Maragheh, Iran .

Study Area: Maragheh, Iran

Coordinates: $37^{\circ} 23^{\prime} \mathrm{N} ; 46^{\circ} 24^{\prime} \mathrm{E}$

Key words: City-development, Environment, Globalization.

\section{$\underline{\text { Abstract }}$}

Due to various fundamental economic and political changes during the last decades, Iran faces One of the challenges that contemporary in achieving the national vision of development is the environmental degradation and sustainability. This is due to the mismanagement of the environment. In other words, there was/is no harmony among economic growth, social development, and environmental protection. Besides, some specific identity has become an increasingly prominent topic in development plans and is considered as a way of identifying people within their social context and one with clear relevance to environmental attitudes and behaviors in society. This paper has focused on a valid input to strengthen the role of identity in architectural designs as a part of the urban context in Iran and described how it is relevant to the natural environment.

\section{Introduction:}

Trends towards globalization in urban life have led to a homogenization in urban identity. This is particularly seen in smaller urban areas, which do not get much attention, and frequently find themselves attracted towards foreign 'solutions', overlooking the traditional value / local identity (Radstrom 2011). On the other hand, the Middle East of Iran is changing very fast from traditional societies and economic systems towards modernization, which has yet to find the real value of stability. It has been seen during many fundamental alterations during urban growth and transition, whether it is in the form of reforming environment or the increase in the number of informal communities and people at the edges of the city. While the origins and evolution of the city around the world are mainly dependent on external factors, thus the Iranian city's traditional evolution and development patterns are also affected by a variety of diverse factors, one of which is the divisions and relations in the social hierarchy.

Indeed, contemporary architects face different challenges as per the user demands in the rapidly developing the technical urban world in every aspect. In particular, the environmental problems whose demand is triggered considerably by the building activities must be of special interest to the architects. While meeting the user needs, it is also questionable to protect the natural sources of the earth and contribute to the protection of the environment.Thus, it is adequate that the preferences are environmental impact-oriented in design and practice. The ability of the architect to make "sustainable" designs that have an environmental sensitivity is closely associated with obtaining knowledge, skill, and capabilities about this subject during the education process (Yuksek, 2013).

The arguing between local and global forces affecting the quality of architecture with two opposing forces. One force trying for protection and promulgation of indigenous architectural local and vernacular traditions, decoration as well as construction methods and technologies. It advocates historical repetition and continuity, cultural diversity and preservation of local identity, all symbolized by a particular vernacular vocabulary of architecture, just as spoken languages and local dialects impart identity. Nevertheless, the other force tries to promote innovation, invention, and dissemination of new forms using new material and technologies in response to changing functional needs and sensibilities. It maintains a systematic flexibility and interchangeability (Lewis, 2002; Ibrahim, 2015).

In recent years, sustainability is no more an optional idea, it has become a major requirement to sustain a certain level of quality of life for the coming generation especially in urban areas. In Iran, the discussions summarized in Table 1 have been related to the idea of

*Corresponding Author:elyar.artistic@yahoo.com 
sustainable architecture from the energy point of view.

Table 1: Different aspects of sustainable energies in Iran

\begin{tabular}{ll}
\hline $\begin{array}{l}\text { Types Of } \\
\text { Resources }\end{array}$ & Potential Prospect \\
\hline $\begin{array}{l}\text { Solar } \\
\text { Power }\end{array}$ & $\begin{array}{l}\text { Iran enjoys plenty of sunshine round theyear with } \\
\text { consistent radiance. Global costs of solar energy } \\
\text { collectionarecoming downannually. }\end{array}$ \\
Wind & $\begin{array}{l}\text { Marginal cost for the wind power technology } \\
\text { develops but inconsistency in wind speed limits } \\
\text { the development. The wind does not blow } \\
\text { uniformlyin someareas. }\end{array}$
\end{tabular}

Hydro Increasing cost for overhead and underground transmission, but have potential competitive energy generating capacity in different zones of Iran. Issues on environmental impacts sometimes leads to relocation of native and local residents.

Geotherma Just found recently in some areas of Iran. Localized energy, with the potential to generate up to $67 \mathrm{MW}$ of electricity per day to meet the energy needs of metropolises.

Biomass/ Substantial resources from some natural sources, Biogas/Waste rubber plantation throughout the country and timber waste from natural rainforests across country. Land used planning and development need to be considered and high carbon reduction compared to solarand wind energy.

Nuclear Technology still not fully developed in Iran and facing international problems. At the moment, only limited amount of electricity is generated in small reactors. Detailed study and development programs should be carried out pertaining to issues on national and international policies.

Energy- Need to be implemented throughout the country Efficiency especially in commercial building in (EE) metropolitan areas in Iran. Architects need to pay much more attention in implementing EE in design and construction.

Ocean Technology is not fully developed in Iran and (Wave/Tidal) there is little potential to harness wave/tidal energy because the wave power density of Iranian ocean is not enough.

To improve the comprehension of sustainable approach in eco-friendly design which must be beyond the technical issues dealt with energy consumption and carbon emission. Further, the principles of resource management, carrying capacity of the planet, cultural and biological variety, and equality between generations are necessary to be adopted in a socially, economically, and ethically applicable design process. Such kinds of values must be applicable into every aspect of architecture job ranging from the idea, building, and management stages of a construction (Altomonte,2011; yuksek, 2013).

This paper deals with an idea of integrating the traditional architecture of the local environmental issues and available resources into contemporary or so-called modern architecture in Iran. The relationship between modern architecture and the climate is always a hotspot in recent studies but is missing the design approach of contemporary buildings. Traditional architecture,which perfectly has presented the principles of climate-oriented architecture has become very popular field for the studies among the new generation of architects and researchers. This paper analyzes the general framework for integrating a native Iranian cultural practice into the contemporary or modern architecture as an approach for strengthen the identity of the country.

\section{Challenges of Sustainability in Modern Architecture of Iran:}

It has been already referred by Ibrahim (2013) that contemporary architecture is diff icult to be identifying as it never represents a clear-cut pattern while analyzing not only in some small neighborhood but through the country. Modern architecture could be suggested as a period from early to the mid-twenty century which was known for its straight lines and also for emphasis on function. Many researchers have stated that contemporary architecture of most countries especially in Asia became an example of internationalism; means the strict eliminating of the local tradition to global masses with no identity or reflection of traditions. Most issues related to the traditional elements of architecture have been overlooked /ignored in modern designs in countries like Iran. However, traditional architectural elements are wealthy in content and consist a rhythm between environment and construction materials, enriching the living conditions and the use of space. A group also believes that if contemporary architecture in Iran could implement traditional element, it could be directed to reach the cultural continuity from the past. Further it could be guided to reach climate-adapted or eco-friendly building and the ideals of sustainable architecture. Today, contemporary architecture of Iran is mainly based on the mechanically controlled environments in order to create comfortable zones and spaces. Thus it increases the rate of energy consumption and thus, it is become important to explore the design concepts of traditional architecture and make a hard attempt to incorporate its characteristics into the design patterns of contemporary architecture.

The term "sustainability" has been applied extensively in scientif ic forums and to many products and activities in the recent years which is generally considered as familiar to everybody. It seems that there are three distinct categories in which sustainability can be discussed, effected and enhanced:
a) environmental sustainability
b) economic sustainability and
c) social sustainability. 
Howfar the architecture and construction industry in the modern era is concerned, there is a strong demand for solutions that provide benef its of sustainability for all of the three sectors. As global warming and climate change have increasingly become the main subjects of political and social concern all over the world. Reduction of energy consumption in buildings in urban areas as well as significant prevention of air pollution and damage to the natural and environmental resources is recognized as a task of highest priority in planning and management levels. As a consequence and in order to provide suff icient and well-protected living environment for the still growing urban population worldwide the building industry is asked to provide more sustainable buildings and spaces whilst simultaneously using fewer materials. Additionally a building's energy consumption during the occupancy and maintenance phase should be minimized not only as a criterion for new buildings but also for existing buildings and particularly public buildings. These parameters and related criteria should be taken into account as well as the context of energy efficiency and refurbishment approaches in heritage buildings. Special attention has always to be paid to the costs involved in building construction and structures. Environmentally sustainable buildings are usually considered to be offending against the fundamentals of economic sustainability if cost-efficiency issues are not taken into account in their design and construction. "Plus-energyhouses" that cannot be afforded by most of the building owners and developers are by no means models for environmental sustainability compatibility. In addition, newly constructed buildings, as well as refurbishment of old and heritage buildings, have to allow for the new and altered social demands of modern and multicultural societies. Light and spacious but well protected urban areas should come along with comfort, energy saving, and aesthetic features in order to create livable spaces where peoplecan meet and interact.

\section{Final analysis:}

Most of the contemporary historians and critics believe that modernism as a moment emerged from Europian countries as the consequences of the changes and transitions which were evolved from the structure of society, culture, politics, and economy as well as the industrial revolution and its consequences. Around the world, the results of such transitions created a new kind of social and urban lifestyle for human society. The scholars like Giedion (2009) believe that a global civilization with a new tradition and new form of spatial imaginations was formed, although it has not progressed and improved in all countries of the world at the same pace and manner. The main goal of modern architecture was to provide new dwelling types for humans in the new modern world. The root factors and situations influencing the formation of modern movement as a social movement can be illustrated in Table 2.

Table 2: The roots of emergence of modern movement and thought in architecture.

\begin{tabular}{|c|c|}
\hline cholars & Situation \\
\hline tis & $\begin{array}{l}\text { Emphasizing on the idea of development and } \\
\text { growth (The modern building must represent the } \\
\text { feature of its eraaswell as the future) } \\
\text { Mistrust toward the tradition of Renaissance and } \\
\text { the partiality theories in that field } \\
\text { Industrial revolution and new methods of } \\
\text { construction } \\
\text { New needs and issues and profound changes in the } \\
\text { social, economicand political structures } \\
\text { Creation ofnew styles and avoiding the imitation of } \\
\text { the past styles }\end{array}$ \\
\hline ene & $\begin{array}{l}\text { - Rejecting traditional thoughts and historicity } \\
\text { - Separation from the past and refrain imitating the } \\
\text { patstyles } \\
\text { - Technological and socio-cultural developments } \\
\text { resulted from industrial revolution } \\
\text { Theidea of creating new style }\end{array}$ \\
\hline idion & $\begin{array}{l}\text { - Minimum use of ornaments in buildings } \\
\text { - Growth and emergence of the new traditions } \\
\text { Redef inition of the human values in architecture } \\
\text { and urban design } \\
\text { - Adaption of the human life with new requirements } \\
\text { and facilities of new era } \\
\text { Def ining the newkind of relationship with the past } \\
\text { (expressing the inner continuity of the past and } \\
\text { present) and avoiding the imitating it } \\
\text { International architectural style and new spatial } \\
\text { imaginations } \\
\text { considering the minimal and modern formal } \\
\text { compositions and optional forms }\end{array}$ \\
\hline Jorberg- & $\begin{array}{l}\text { - Sense of relief in new world (identification of } \\
\text { naturaland social environments in society) } \\
\text { Provision of new settlements in new world for } \\
\text { human } \\
\text { - New international conditionsfor architecture and } \\
\text { rejecting the past forms of buildings } \\
\text { Newand rational spatialand formal imaginations } \\
\text { Tendency towards logic and modern art and } \\
\text { scientif icstudying of artisticphenomenon } \\
\text { Increase in the dualities of logic and emotional } \\
\text { thoughts }\end{array}$ \\
\hline & $\begin{array}{l}\text { Influences of Renaissance and the advent of } \\
\text { rationalismand humanism } \\
\text { - Avoiding the religious thoughts } \\
\text { - Scientif ic tendencies towards modern thoughts } \\
\text { Enlightenment era and the rationalism } \\
\text { Industrial revolutionand its consequences }\end{array}$ \\
\hline
\end{tabular}

Along with political, socio-cultural and economic transformations in Europe, Qhajar government in Iran has established an Amir Kabir's actions paved the way for the arrival of modern thoughts and ideas in the early era of 
Nasser-Al-Din Shah. These countries were looking for further expansion and influence in other countries of the world, and thus they got inclined towards Iranian government because of Iran's strategic situation in Asia with accessibility to the Persian Gulf, China, and India. At that era, the Netherlands, Germany, Britain, France, and Russia were among the countries which had large amount of political and economic relations with the Iranian government and had a remarkable influence on the political attitudes of the politicians (Habibi, 2011). Therefore, it was felt that western-style changes were necessary for the political, socio-cultural and economic structure of Iran in that period, and started the changes (Naghdbishi et al., 2015). Some reasons, which led Iran to a modern society (however it seemed Syncretistic), have been summarized in Table 3.

Table 3: The Reasons of emergence of modernism in Iran

\begin{tabular}{|c|c|}
\hline Scholars & Reasons \\
\hline abibi & $\begin{array}{l}\text { The domination, relationship and influences of } \\
\text { European colonial governments on Iranian } \\
\text { government } \\
\text { The tendencies of merchants and aristocrats } \\
\text { towards relation to Europeand othercountries } \\
\text { European graduated students with academic } \\
\text { education who arrival in Iran and worked in } \\
\text { Iranian universities } \\
\text { The enter of European advisors and engineers to } \\
\text { Iranian industry } \\
\text { Import of the new technologies such as telegraph, } \\
\text { telephone, printing machine } \\
\text { Emergence of the new architectural functions } \\
\text { suchacinema, theater, bankand hotel }\end{array}$ \\
\hline & $\begin{array}{l}\text { - Enter of the foreign counselors } \\
\text { Exchange of the educators and labors with } \\
\text { Europeancountries } \\
\text { Construction of some new industrial institutions } \\
\text { based on newstyle of life } \\
\text { - Translation of the foreign books into Persian } \\
\text { Arrival and activities of the European and } \\
\text { American merchants and trading companies as } \\
\text { wellas missionariesto Iran } \\
\text { - Urban Infrastructures and several qualitative } \\
\text { reformations and changes in government } \\
\text { organizationand structure } \\
\text { Social, cultural and economic reformations across } \\
\text { society (new and modern education systems and } \\
\text { establishment of modernschoolsand universities) } \\
\text { Colonial influences ofsome European foreign } \\
\text { countries, especiallyBritainand Russia } \\
\text { Travels of the King, ministers and major } \\
\text { merchants to Europeancountries } \\
\text { I m p r t of the n e w te ch n o l o g ic a l } \\
\text { achievements }\end{array}$ \\
\hline Bani & $\begin{array}{l}\text { Organization of the stable and powerful central } \\
\text { government in Iran } \\
\text { Attendance and intervention of the powerful } \\
\text { Europeangovernmentsto Iran }\end{array}$ \\
\hline
\end{tabular}

- General education of the Iranian students in European countries and reforming program of "new systems" of education

- Exploitation of the foreign engineers and technicians in domesticindustries

- Establishment of new universities, factories and institutions based on European style of industry

- Travel opportunities to Europe (The King, courtiers and merchants)

- Import of new inventions and technologies

- Political, social and economic reformationsunder western capitalists influences

The situation and condition of architectural evolution in Iran, especially in Qhajarera, caused many cities to encounter the changes and reformations in the sake of both national and international factors. These changes occurred in different fields of politics, economy, society and alsoarchitecture and urban design. New modern buildings were resulted from those changesin major cities and urban areas.

\section{Conclusion:}

Since physical structures of cities are becoming more complex, there is an immediate need for transformation of current urban structures (Moosavi, 2016). One of the significant impacts of contemporary architecture on urban spaces of Iran is the inclination to the global trends of globalization. Such changes in urban environments are often due to changing lifestyles and social norms, which are important factors in identity of urban spaces. One of the major and important concerns related to the local identity in urban areas and related research is on the sustainability of place identity created by architectural space as well as buildings and commercial spaces, especially in urban areas. In this article, we have tried to establish that the traditional architecture in contemporary Iran has had its distinguished style that reflected the real taste of the people, who have built their houses and of those spaces who have lived in them for centuries. But, unfortunately, this taste and style have not been introduced to modern architecture in contemporary society of Iran.

However, at the social and urban level, or production of urban architecture, things should be mediated as cultural ingredients and shall be considered on a global scale. So that the measures and policies in this sense should take into account matters of substances in directing an entire local identity and regional governance policies to exploit both heritage values and innovative architectural achievements and technologies. Considering the general approach of architectural and urban professionals towards the fields like sociology, anthropology, political science, things look much more simpler, and the approach targets the users of space which are the main barometer to establish ethics of beauty, satisfaction, and value depending on options. It should be concluded that apart from globalization, architecture is a living and dynamic generator of reality that continually changing and influencing the human society. Therefore, in the current condition of modern or contemporary, we shall get ready for confronting the phenomenon of local identity and ecosystems or environment by paying more attention to opportunities and threats arising from globalization procedure and global culture. In addition to retaining local identity while saving the environment through architectural design and construction and also applying the tools 
GENERAL ARTICLE

derived from global culture, architects should try to universalize by relying on our Iranian historic culture because, architecture is the creative and imaginative product of human society that more than any other product determines its container and contents in society.

\section{Acknowledgements:}

The authors are thankful toall such off icials and persons who had directly or ideirectly helped us to conclude this part of study.

\section{References:}

Altomonte, S. (2011): Handle with care. The challenges of sustainability and the agenda of architectural education. Mimarist J., 41:52-6o (in Turkish).

Giedion, S. (2009): Space, Time and Architecture: The Growth of a New Tradition, 5 ed., p. 96o; Pub. by: Harvard University Press

Habibi, S.M. (2011): Intellectual Trends in the Contemporary Iranian Architecture and Urbanism (1979-2003). Pub. by: Cultural Research Bureau, Tehran.

Ibrahim, H.G.A. (2013): Contemporary architecture through the concept of regionalism: a sustainable approach for Doha Qatar. Int.J.Sustain. Hum. Develop., 1(3):94-103.
Ambient Science, 2018: Vol. 05(1); 01-05 DOI:10.21276/ambi.2018.05.1.ga01

Ibrahim, H.G.A. (2016): Regeneration of sustainability in Contemporary Architecture: Approach Based on Native Function and Activities to Strengthen Identity. Procedia Soc. Behav. Sci., 216:80o-809.

Lapidus, I.M. (1969): Middle Eastern Cities. Pub. by: Berkeley: University of California Press.

Lewis, R.K. (2002): Will forces of globalization overwhelm traditional local architecture? Washington Post, 2, 2oth November, 2002.

Moosavi, M. S. (2016): New Methodologies of Education and Research in Urban Studies. Iran. Online J. Urban Res., 1(1):1-4.

Naghdbishi, R., Barghjelveh, S., Islami, S.G. \& Kamelnia, H. (2015): The Qualitative Analysis on Contemporary Approaches toward Architectural Training in Iran. Int. I. Architec. Urban Develop., 5(3):63-72.

Radstrom, S. (2011): A Place-Sustaining Framework for Local Urban Identity: an Introduction and History of Cittaslow. Italian J. Plan. Prac., 1(1):90-113.

Yüksek, I. (2013): The Evaluation of Architectural Education in the Scope of Sustainable Architecture. 2nd Cyprus International Conference on Educational Research, (CY-ICER 2013). Procedia-Soc. Behav. Sci., 89:496-508. 